\title{
Fungal Infection of Ear And Its Sensivity Pattern
}

\author{
5. If. faiscal
}

\section{Summary}

50 cares of ctomycosis were subjected to culture for furgi. All cultures were pu: for antifungal drug senotivity. Econazole, Clotrimazole and Silver Sulphadiazise wore found to be most efective in all types of fungi isolated from culture. It was observed thet had hygienic condition \& rural poputation suffer mostly.

\section{Introduction}

Virchow first introduced the tem nycosis of fungal infection. Fungus is a member of phylum Thallophyta of plant kingdom. They are devoid of chlorophyl o? arif other pigment. Hence they are not capable of photosynthesis, which is the characteristic feature of plant kingdon, Fungiate either saprophyie or parasite in nature. About soveny spocies of fungi are found. In the present sories four species of fungi have boen isolated from ear and their stensitivity patrerri studied.

Material and mellod

50 cases of otomycosis were taken. Detail hictory of the case with priticula

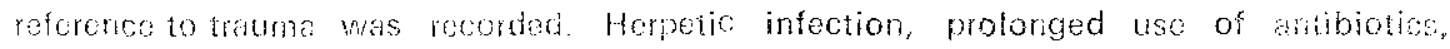
corticosteroids in form of diops or ominents, radiation exposure, tuberculosis, topresy. cancer, of diabetic;, were all considered in history.

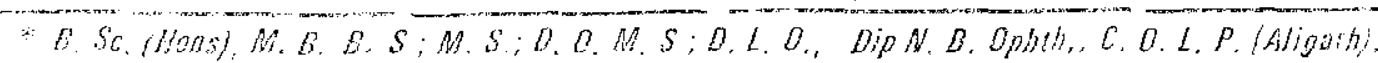
licyistar, Dopt of E. N.T.

Patma Modical Colloge a Hospitol Patma, Bihar, Hotis. 


\section{rougus studies}

Fungel studios were carried out by:

i. Direct Microscepic oxamination.

2. Culture of the scrapped metorid

3. Ancolptutimu wire loap aheady sterized by heating yed hot was used to take scrap gentuly No andeshetic was usad. Scral was spread over a glass rite over a drop of 10. potesium hydroxide solution and then covered with cover ship. Slide wes hemed over bumer just boiting, and cxamined under microscope.

I'. The seroped moterial was cultured over Sabouraud's rodia a fungus identified by

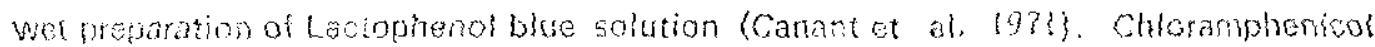
was adod to the media to pravent the growth of any bacteria. It was autoclised bo

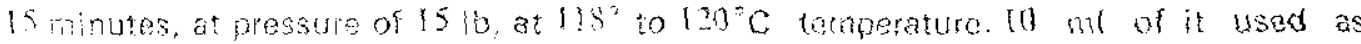

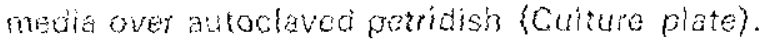

Fungas cuhure

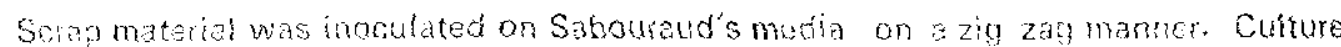
phate was hept in iroubor at 20 ' $\mathrm{C}$ and observed every alternate oy for fungal giowh up to six mecks.

The growh uns observed for the following:

1. Rato of gramin

2. General marphology of colony

* Toxine Yeast lika, powdery, granular, veluety cotton ato.

4. Surface pigmentation colour of pigment.

A small part of fungal colony was ploed over a ghas slide with the

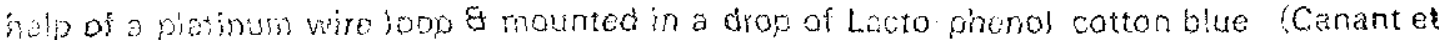
B) 1974). Fungus separated with needies. After puting covarsib, fungal study was done under migroscone. Yeast hiso fungt were also examined by suspending a loopfut culture in a drop of water covered with coverstip.

A repeat culvure was deso done in positive cases

\section{Drug Sensinity Study}

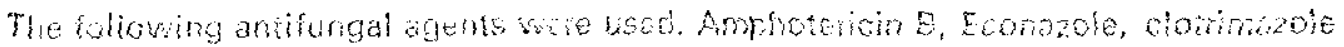
Miconazole. 5 fluorocyusine sodium stacetemide $20 \%$ it silver suphediaze 1 .".

Solutions wete prepared by dissolving 1 gm of drug in:

A) $10 \mathrm{ml}$ of dimethyliamanide for Amphosericin $\mathrm{B}$

E) $10 \mathrm{ml}$ of polethyoneghool for imidozoles folotrimazole. Econazoia Miconazole: 
c) $10 \mathrm{ml}$ of $0.01 \mathrm{M}$. phosphate buffer for 5 fluocylosine. These solutions contained $100,000 \mathrm{ug} / \mathrm{m}$ !

n) Sodram: Suphacetamide solution $20^{\circ} \%$.

E) Silver sulphadiazine solution 1",".

Artiongal compound disc

1. Disc (9 mm. in diameter) ware cut from whatman filier panel.

2. The discs autoclaved for 30 minutes.

3. The discs driend in loot air oven.

4. Discs of various strength 1,5,15 \& 25 i. e. concentration we prepated.

\begin{tabular}{ccc}
\hline Disc concentration & Drop & Solution concontation \\
\hline 1 & 1 & $20 \mathrm{ug} / \mathrm{m}$ \\
5 & 1 & $100 \mathrm{ug} / \mathrm{ml}$ \\
15 & 1 & $300 \mathrm{ug} / \mathrm{ml}$ \\
25 & 1 & $500 \mathrm{ug} / \mathrm{m}$
\end{tabular}

5. The discs stored at 4 ' $\mathrm{C}$ in sterile comtainet after drying in incubator.

The discs of difiercht drugs were placed on Blood agar modium. Fundi were moculated at $37^{\circ} \mathrm{C}$ with a large vire loop into the medium. Degree of sensitivities wore sec in order of the zone of inhibition (in $\mathrm{mm}$ ).

$$
\begin{aligned}
& 11-15 \mathrm{~mm}-1 \text {-... Poor } \\
& 16 \ldots 18 \mathrm{~mm}-\mathrm{m}_{-1} \quad-\text { Mild } \\
& \text { 19) - } 22 \mathrm{~mm}-1 \cdot 1 \cdot \mathrm{i} \text { - Moderate }
\end{aligned}
$$

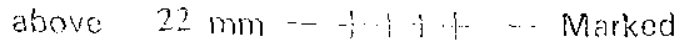

iocally.

All cases vero treated by analgesics of antibiotics orally, and antiungal drops

Observations

Out of fifty cases of otomycosis 20 were from uban area sind 30 were from

\begin{tabular}{|c|c|c|c|}
\hline $\begin{array}{l}\text { Totat No. of cases } \\
\text { of corneal ulcer }\end{array}$ & Aroa & $\begin{array}{l}\text { No. of fungus } \\
\text { positive cose }\end{array}$ & Percentage \\
\hline & UBBAN & 20 & 40 \\
\hline 50 & RURAL & .30 & 60 \\
\hline 50 & $\ldots-$ & 50 & 100 \\
\hline
\end{tabular}
iural area

$T+b a^{2}-I$ 
Table- II

Among io cases of Otomycosis the following was the distribution anong
ccupation. ditteront occupation.

\begin{tabular}{|c|c|c|}
\hline Cocupation & No. of cases & Percentag \\
\hline 1. Farmers & 20 & 40 \\
\hline 2. l.abourers & & \\
\hline (a) Village farm labourer & 10 & $20 \%$ \\
\hline (b) Urban labourer & 10 & $20^{\circ}:$ \\
\hline 3. House wives & 3 & 6 \\
\hline$\therefore$ Ofice employeo & 2 & $4{ }^{n}$ \\
\hline 5 Studerts & 2 & 4 \\
\hline 6. Eusiness class & 3 & $6^{\circ}$ \\
\hline
\end{tabular}

Table 11 shows that otomycosis is common among rurat a poor class.

Table- III

Shows incidence of otomycosis resulting from diffeant types of trauma.

\begin{tabular}{|c|c|c|}
\hline Trauma due to & No, of cases & Percentag \\
\hline i. Mechanica! & 4 & $8^{3}$ \\
\hline \multicolumn{3}{|l|}{ 2. Organic matter } \\
\hline (a) Animal origin & 2 & $4:$ \\
\hline (b) Vegetable origin & 6 & $12 \%$ \\
\hline 3. Metallic particle trama & 1 & $2 n$ \\
\hline$\therefore$ Other types of foreign body & 2 & 4 \\
\hline 5. Local use of antibiotic crop and cortisone drop & 8 & 16 \\
\hline$\therefore$ Suppuroive ozitis media & 7 & $1: 3$ \\
\hline 7. Wo history of traume & $31)$ & 40 \\
\hline 8. Operative & 0 & $-\cdots$ \\
\hline Total & 50 & $100^{\circ}$ \\
\hline
\end{tabular}

Fungi isolased fromi ear.

\begin{tabular}{|c|c|c|}
\hline Fungus specios & No. of isolation & Percortege \\
\hline 3. Cancidálicicans & 23 & $40^{\circ}$ \\
\hline$\therefore$ Asperginus niger & 17 & $2 \mathrm{~N}^{2}$ \\
\hline 3. Thinopus & 6 & $12^{3}$ \\
\hline \multirow[t]{3}{*}{$\therefore \quad$ Fusmiun speries } & 4 & $8^{n}$ \\
\hline & 50 & \\
\hline & $-38-$ & \\
\hline
\end{tabular}




\section{Table- V}

Showing sensitivity test to vorious antifungal agents and antibiotics.

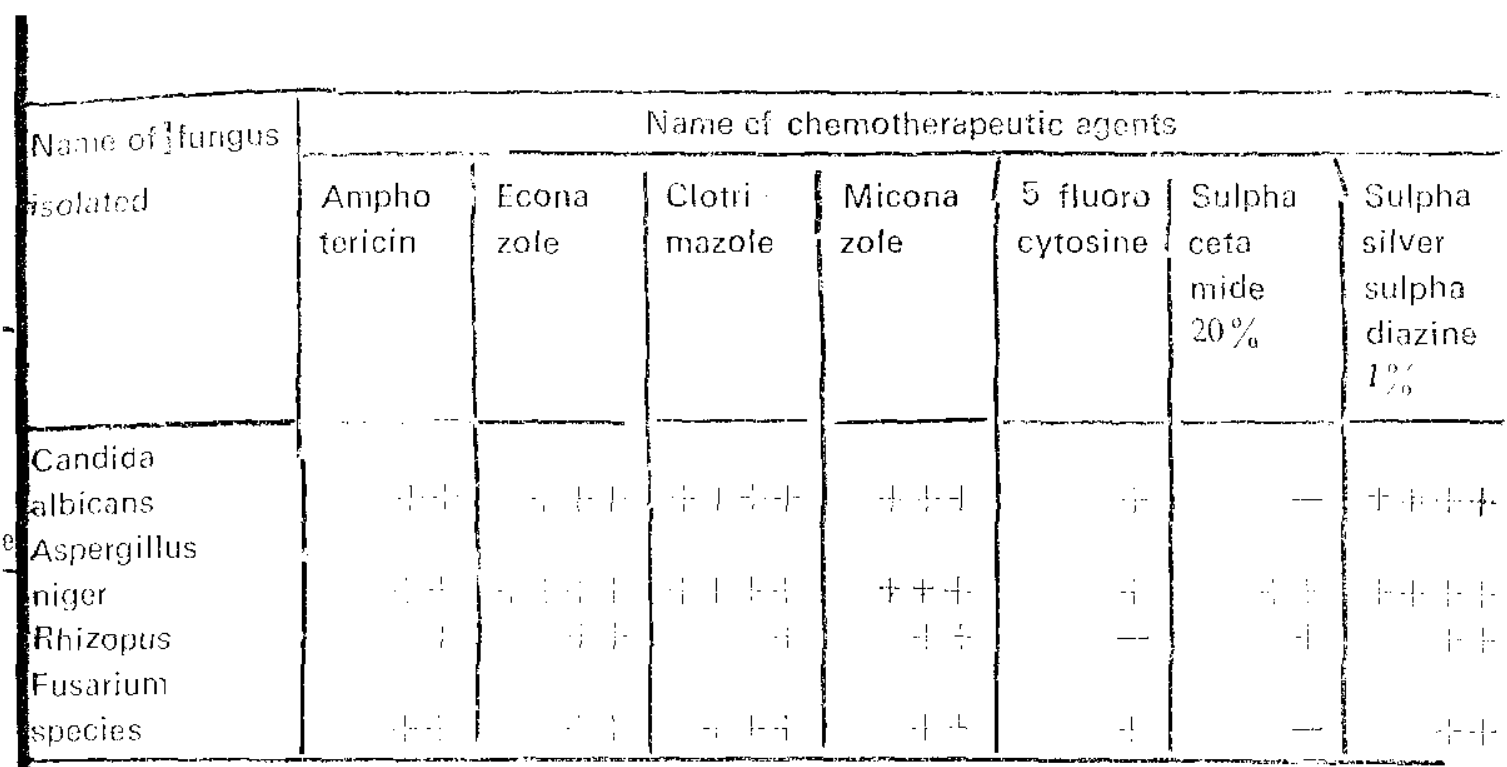

Four degrea of zone of fungal growth inhibition are:
a - marked
22 mm or above of fungal growth inhhitition
$\cdot 1 \cdot \cdot \cdot \cdot \cdot \cdot \cdot-1-$
b. - maderate $19-22$ mm of inhibition
$-1--1-$
$c$ mild $16-18 \mathrm{~mm}$ of intibition
$+1-1-$
d) poor 11-15 mm of inhibition

\section{Discussion}

Otonycosis is one of tho commonest finding in India during liny season. A large bulk of people suffer from this disease in Bihar State. In India majority of the ppowation live in villages. Illiteracy, povery poor hygiene, lack of healh cducation and medical care. all contibute to fungal iniection of ear. Otomycosis goos unnoticod \& urattonded unit it causes sevore pain.

The revicw of literature on Otomycosis in India reveals spondic case reporis.

The regional epidemiological data on otomycosis are lacking in India. This study reveals

the typos of fungi provalent in this part of the state causing otomycosis and its sensitivity 
to varous drugs. This will help in carly convalesence of paíant.

The results in this series reveal that fungal ear infection is more prevalent riral population 60\% as compared to urban population. The rual workers are more exposed to spores of fung in the rural atmosphere and soil, hence the higher incidonco in rual populption noted. They are also prone to various types of trauna by organic retter leading to otomycosis.

The species of fungi isolated from external auditon canal were Candida abicans, Aspergillns niger. Fhizopus and Fusarium. Condida albicans $\left(46^{\circ}\right.$ u) was the commonest cause of oromycosis, the next being Aspergillus niger $(34 \mathrm{u})$.

The sensitivity test conducted showed that Amophotoricin $\mathrm{E}$ as mildy oreative against the various fungus culture in present study. isolated from ear.

The 5-fluorocytosine was found to be poorly sifective in all types of fungh

Econazole was found to be moderately effectiv runse Cardida abicans and markedly effective against Aspergillus niger, but was poori, against Rhizopis and mildy efoctive against Fusarium.

Miconazole was moderately effective against Candida albicans and Aspergillus riger and mildy aganst Rhizopus and Fusarium.

Niconazolo \& Econazole are subsituted pherethy alcohol inidazoles with brosd spectruin anifungal acivity and low mammalian toxicity (Codefroi et al 1969 ) Jiconazole is less tolerated than Eoconazole. Econazole is found to be highly senaitive 10 fungi.

Clotrimazole was markedly effective against Candida abions and Aspergibus rigar, moderately ageinst Fusarum and poorly agaisnt Rhizopus. Clotrimozole is less toxic but having broad spectrum antifungal activity (thoffbind et al, 1974). As clotrmazolo induce dug metabolising erzymes in the liver, it is better to givo boh topically g orally to andeve maxinum blood level.

The suffoctamide, our oldest drug, is stift mibiy effective against ribet of obo flungi.

Tho latest drug which is used to treat bun cases. Siver sibphadizino was also usod by author to see its scrisitivity to various fungi. It was found to be

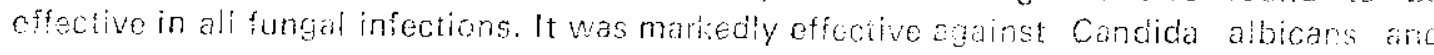
Aspremillus niger and middy aganst Ribizopus and Fuseriun.

Therofore therapy with Econozole or clotrinazole and a newer drug siver si-phadiazine can be sefoly s effectively instituted in an established case of otomycosis ruth the resulis of culture and sonsitivity is rot avaliablo 


\section{References}

1. CONAHT., N. F., SMTH, D. T. BAKER, R. D., CALLAWAY, J. L. AMO MARTII, D. S. (1971): Mantial of Clinical Alyoloty, 3nd Ed. Philadelphia, Saunders.

2. GOOFFOI, R. F, HEOAES, J. VON CUTAEM, J.M \& JONESEN, P. A. J. (1960): The prepartiof and Anti niycotic propartids of dorivatives of 1. Phonethyl imidazole. d. Med. Chem. 12:794.

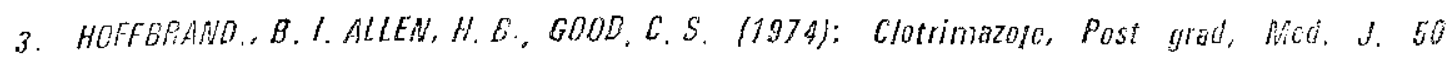
(Supp),

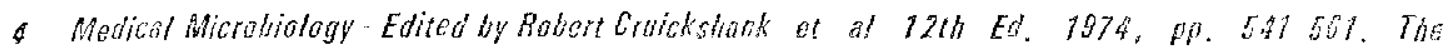
E. L. B. S. Q Charchill Livingtione G. B.

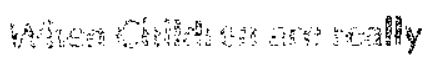

miss

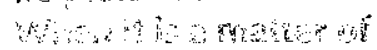

W......

s.

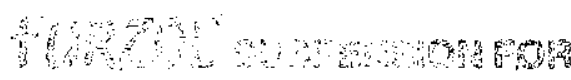

" $\mathrm{AmbH}$ -

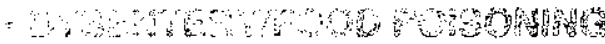

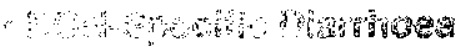

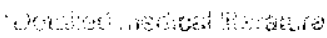

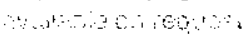

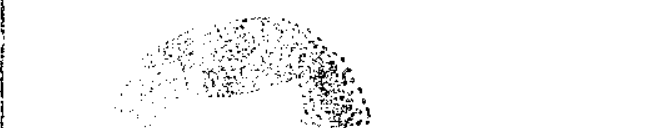

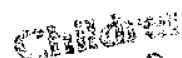

monthos

$\mathrm{Th}$ ens? 3

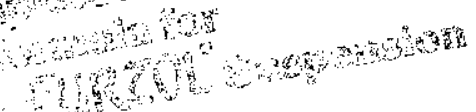

Prot $5 \mathrm{nin:}$

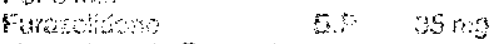

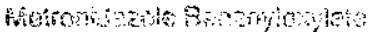

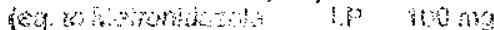
Foctir

Lightit tont:

Golationt

Patom

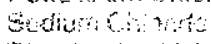

bicurdinat

i.

If 8 ing

1. 40,03

if 60

$\therefore$ ip $100 \mathrm{~min}$

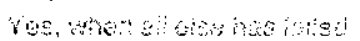

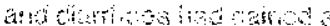

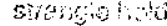

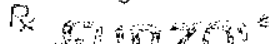

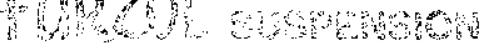
and

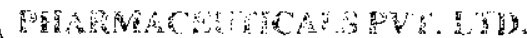

re moroy ist r.tom

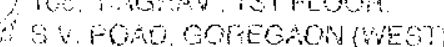

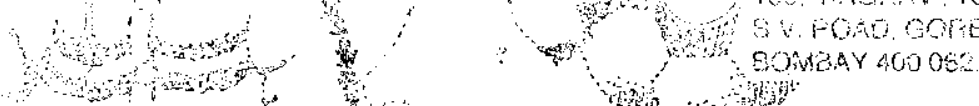

in ... 